Revue Française de Civilisation Britannique

\title{
The consequences of the 2008 crisis on Britain's Inflation Targeting Framework
}

Les conséquences de la crise de 2008 sur le cadre britannique de ciblage de l'inflation

\section{Nathalie Champroux}

\section{(2)enEdition \\ Journals}

\section{Electronic version}

URL: http://journals.openedition.org/rfcb/1121

DOI: $10.4000 /$ rfcb. 1121

ISSN: 2429-4373

Publisher

CRECIB - Centre de recherche et d'études en civilisation britannique

\section{Electronic reference}

Nathalie Champroux, «The consequences of the 2008 crisis on Britain's Inflation Targeting

Framework », Revue Française de Civilisation Britannique [Online], XXI-2 | 2016, Online since 16 October 2016, connection on 30 April 2019. URL : http://journals.openedition.org/rfcb/1121 ; DOI : 10.4000/ rfcb.1121

This text was automatically generated on 30 April 2019.

\section{cc)}

Revue française de civilisation britannique est mis à disposition selon les termes de la licence Creative Commons Attribution - Pas d'Utilisation Commerciale - Pas de Modification 4.0 International. 


\title{
The consequences of the 2008 crisis on Britain's Inflation Targeting Framework
}

\author{
Les conséquences de la crise de 2008 sur le cadre britannique de ciblage de \\ l'inflation
}

Nathalie Champroux

1 The financial crisis that started in the summer of 2007 in both the United States and the United Kingdom represents a turning point in the economic history of most developed countries. It tipped the Western world into economic turmoil, thus wiping out several decades of economic stability, and called into question many of the macroeconomic theories that had developed over these decades. In the United Kingdom, the systemic financial crisis that rolled out proved "unprecedented in scale" ${ }^{1}$ and the subsequent recession lasted four quarters in a row over 2008-2009. Yet, the British authorities had reacted strongly, as soon as the signs of economic dysfunctioning had been recognized.

2 Among all the measures that the British authorities enforced, this article examines the monetary policy response to the crisis. In particular, it seeks to understand whether, beyond the activation of unconventional practices, the crisis caused a major restructuring of the United Kingdom's monetary policy framework. The first section briefly recalls what British monetary policy consisted in before the crisis. The second and third sections show how New Labour, and then the coalition Government, responded to the 2008 crisis and its aftermath within the framework. The fourth section determines how the reform of monetary policy of 2013 altered the fundamentals of the framework and the fifth section places the reform in the context of the progress of monetary theories. 


\section{Britain's Inflation Targeting before the Crisis}

3 Since October 1992, British monetary policy has officially been dedicated to price stability, through a framework of inflation targeting (IT) that was first improvised by the Conservative Chancellor of the Exchequer, Norman Lamont. The framework was strengthened five years later by New Labour's Chancellor of the Exchequer, Gordon Brown, especially through the adoption of the Bank of England Act 1998.

Regarding monetary policy ${ }^{2}$, the law confirmed that the objectives of the Bank of England were "(a) to maintain price stability and (b) subject to that, to support the economic policy of Her Majesty's Government, including its objectives for growth and employment." To realize these objectives, the Bank would comprise a new entity of nine members, a Monetary Policy Committee (MPC), enjoying complete operational independence in "formulating monetary policy" (i.e. setting the level of interest rates). The law also said that the Treasury would specify annually to the Governor of the Bank of England, "(a) what price stability is to be taken to consist of, or (b) what the economic policy of Her Majesty's Government is to be taken to be."

5 The law also reinforced transparency and accountability, with an obligation to publish a statement each time the decision of an intervention was made, the minutes of the meetings and monthly reports, and with the surveillance of the MPC's procedures by a Parliamentary "Oversight Committee". A last section dealt with the Treasury's "reserve powers", that is to say the right to dictate operational actions to the Bank in "extreme economic circumstances", with the prior approval of Parliament ${ }^{3}$.

6 In his new monetary policy framework, Brown refreshed the target for inflation, replacing the target range by a symmetrical point. More importantly, the 1998 Budget also specified that even though the target was valid "at all times", temporary deviations could occur. As a means of information and accountability, the obligation was introduced for the Governor to send an open letter to the Chancellor, should inflation be more than one percentage point higher or lower than the target. The letter should explain the situation and the MPC's plan to reverse $i^{4}{ }^{4}$, which sounded much like a provision already made in 1992 by Lamont ${ }^{5}$.

7 The framework then remained unchanged for five years. On 10 December $2003^{6}$, two changes were introduced. First, the Chancellor announced the inflation target was now based on an internationally recognised measure, the Harmonised Index of Consumer Prices (HICP, renamed Consumer Prices Index or CPI), instead of the RPIX. The change induced the setting of a new target value, at $2 \%$. Second, it was the start of the publication of the Chancellor's remit for the MPC. Since then, the remits, and the letters that introduce them, have been the reference documents fixing the rules of the monetary policy framework.

8 Ten years later, the assessment of the IT framework displayed gratifying results. Since the inception of IT at the end of 1992, until the improvement of the framework in 1997, average inflation as measured by RPIX was only $2.7 \%$. It decreased again down to $2.5 \%$ from 1998 to $2005^{7}$. As measured by CPI, inflation was 1.5\% on average between 1997 and $2007^{8}$. Over this last period, the actual inflation rate never deviated by more than one percentage point from the targets. The truth is inflation had already been decelerating 
even before the beginning of IT in 1992. But since then, stability had been remarkable, both in terms of inflation and GDP growth, hence the reference to the nice decades.

The stability was probably enhanced by other factors than monetary policy only. At the beginning of 2007, a study made by the Bank of England's experts reckoned there were domestic but non-monetary factors too, like the supportive fiscal framework, and also other external factors, due to the integration into the world economy of emerging countries and to immigration ${ }^{10}$. Yet, the experts demonstrated the effectiveness of the IT framework and institutional arrangements. This effectiveness was put into question by the 2008 crisis.

\section{The Monetary Responses to the 2008 Crisis under New Labour}

British Governments and the Bank of England took numerous actions of a massive scale to pull the United Kingdom out of the financial crisis and subsequent recession. In the flow of interventions, it was rather difficult to distinguish clearly between monetary and financial (or banking sector) actions. It is therefore necessary to recall official definitions to avoid confusion. The Bank of England only lists under the appellation of "monetary policy operations" the setting of the Bank Rate, the injection of money directly into the economy by purchasing financial assets (Quantitative Easing) and Forward Guidance ${ }^{11}$. The Treasury confirms, by not inventorying any of the former as a financial policy intervention. It also considers the Asset Purchase Facility established in 2009 as the concrete means to finance the Quantitative Easing programs ${ }^{12}$.

The first monetary actions that were taken were the cuts in the Bank Rate, which commenced in December 2007 and ended in March 200913, under the leaderships of Gordon Brown as Prime Minister and Alistair Darling as Chancellor. The first wave of cuts occurred from December 2007 to April 2008 and reduced the Bank Rate down to 5.0\%. The MPC justified the cuts by the risk of too low inflation in the medium term that accompanied the prevision of a sharp slowdown in economic activity ${ }^{14}$. The Committee proved right: Inflation was actually below $2 \%$ between June and November 2009, hitting a low of $1.09 \%$ in September ${ }^{15}$. The second wave of cuts occurred between October 2008 and March 2009 and brought the Bank Rate down to $0.5 \%$. The first reduction was part of one of the rare international concerted actions in response to the unexpectedly massive scale of the economic crisis ${ }^{16}$. Yet, the MPC justified it, and all the others that it decided, by the need to compensate for the risk of inflation undershooting the $2 \%$ target in the medium term. Among the risk factors, the Committee identified the domestic recession, which increased spare capacity and pushed wages and companies' margins down, and the fall in energy and food prices ${ }^{17}$.

All the interest rate cuts, which responded to the crisis situation, remained within New Labour's monetary policy framework. First, the Government did not use its reserve power to dictate the interest rate levels or the timing of change. Not only did the Chancellor let the MPC's experts do their job, he also always endorsed the Committee's operational decisions, whatever the situation. At each target overshooting, for example, he publicly expressed his agreement with the MPC's justifications and forward-looking decisions ${ }^{18}$. Second, officially, the ultimate objective of monetary policy never stopped being the control of inflation. Helping with output was presented as a means to reach this objective, 
not the contrary. As a result, the remits did not encounter any modifications under New Labour. Only the Chancellor's accompanying letters varied slightly, with the mention of the emergence of global challenges and some references to the Asset Purchase Facility.

The Asset Purchase Facility (APF), launched on 29 January 2009, is an arrangement under which the Bank of England is authorized to purchase high-quality assets from the private sector, the list of which is validated by the Treasury. In March 2009, the Chancellor permitted the MPC to use the APF as a monetary policy instrument, with the financing of asset purchases through the central bank's creation of money. This way of injecting money directly into the economy is known as Quantitative Easing (QE). There were four waves of purchasing government bonds (gilts), but also commercial paper and corporate bonds, from March to November 2009, for a total of $£ 200$ billion. In January 2010, the Bank of England then started selling as well as purchasing corporate bonds in the secondary market. And in February, the Treasury allowed the Bank to continue to do so, but required the future purchases to be financed by the issuance of Treasury bills.

Just like the manipulation of interest rates, QE was implemented within New Labour's monetary framework and dedicated to IT. It was conceived as an alternative to the Bank Rate instrument, which could not be reduced further, whereas the urgency to support the recovery in nominal spending persisted. In the minutes of the meeting held in February 2009, which set the case for the use of APF for monetary purposes, the MPC repeated no less than four times that the unique motive was to meet the $2 \%$ inflation target, and insisted on the importance of diffusing this message when communicating about the MPC's actions ${ }^{19}$. In his letter dated 3 March 2009, which officially authorized QE, Darling therefore confirmed the Committee's objective of price stability ${ }^{20}$. In his following letters, "price stability" was simply replaced by "monetary stability" ${ }^{21}$ ". Since QE operations, financed by the APF, were just seen as a supplementary monetary instrument, on the same level as the Bank Rate, the MPC was accountable for any of its decision regarding this new instrument, through the existing system of publication of Inflation Reports and evidence to the Treasury Committee.

Even if the exact effects of the Bank Rate cuts and the QE programmes on the United Kingdom's economy cannot be accurately assessed, because all other things are never equal, all analysts agree the interest rate cuts were the thing to do and the crisis would have been deeper without $\mathrm{QE}^{22}$. Yet, at the beginning of 2010, with GDP growth still lower than $0.5 \%{ }^{23}$ and inflation back to above $3 \%$, the British population had no reasons to rejoice. In its discontent, the electorate voted against New Labour on 6 May 2010.

\section{The Conservatives' Extension of Existing Responses}

16 The new coalition Government, led by Conservative Prime Minister David Cameron, assisted by Liberal-Democrat Deputy Prime Minister Nick Clegg, and Conservative Chancellor George Osborne took over a context of high inflation. This context lingered for more than two years, while growth showed no signs of recovery. During this period, the Government reinforced the measures implemented by its predecessors.

Osborne affirmed the new Government's commitment to maintaining price stability and pursuing the $2 \%$ inflation target just after arrival in power $^{24}$, and confirmed the target in each remit for the MPC that he sent from March 2011. It should be noted that his first remit, which was faithfully replicated afterwards until 2013, showed few modifications 
from Darling's remits. Furthermore, these modifications were only related to the new Government's beliefs and objectives, but not to monetary policy itself ${ }^{25}$.

Concerning the MPC's monetary policy operations themselves, while inflation accelerated throughout 2010 and 2011, Osborne accepted the Committee's decisions to keep the Bank Rate close to the zero lower bound. In addition, he allowed for the rise in the amount of the APF available for QE interventions, up to $£ 375$ billion by July 2012. As a matter of fact, the new independent economic analysis institution, the Office for Budget Responsibility, that the Conservatives had created, always validated the MPC's inflation previsions in the medium and longer-term. These previsions were that inflation would eventually return to the $2 \%$ target in the medium term, with a substantial risk of undershooting because the economy was still struggling.

Indeed, the steady recovery experienced after the deep trough of the last quarter of 2008 suddenly came to a halt in the second quarter of 2010. Until the first quarter of 2013, GDP growth was very volatile, sometimes negative, and never as high as $1 \%{ }^{26}$. So it was certainly not the right time to prevent the MPC from practicing monetary ease. Actually, monetary ease - or "monetary activism" - was the counterpart to fiscal austerity in what the Chancellor later labelled the Government's "economic strategy ${ }^{27 "}$. Yet, the strategy was not presented as such. Rather, Osborne claimed that the commitment of the Government to reduce the budget deficit created a fiscal credibility supportive of the recovery, and of price stability and so, in turn, allowed monetary policy to be loosened so as to stimulate the economy ${ }^{28}$.

20 There was nevertheless a limit beyond which monetary policy could not be loosened further without risking to fuel inflation and disrupt the financial market structure too much for a smooth return to normal monetary policy in due course. Even though from November 2012 some MPC members started voting in favour of raising the APF to $£ 400$ billion, most members argued against the measure and voted accordingly ${ }^{29}$. The disturbing disagreement went on even after Governor King had been succeeded by Carney in July 2013. But in the meantime, the coalition Government had asked the MPC to examine the opportunity of implementing other monetary instruments. In August, the Committee opted for Forward Guidance, in the wake of several central banks ${ }^{30}$.

\section{The Next Phase: The 2013 Monetary Policy Reform}

21 Forward Guidance (FWG) is a form of communication dedicated to managing the market participants' comportments by influencing their expectations of future monetary policy. In the United Kingdom, the MPC first proceeded in August 2013 by adopting a proposal stating its intention "not to raise Bank Rate from its current level of $0.5 \%$ at least until [...] the unemployment rate [had] fallen to a threshold of $7 \%^{31}$ ". As the unemployment rate approached the threshold, the message was reviewed in February 2014. The MPC announced it would "seek to close the spare capacity in the economy over the next two to three years while keeping inflation close to the target ${ }^{32}$ ". Spare capacity was evaluated at broadly $1 \%-1.5 \%$ of GDP, but the pace at which it would be absorbed remained unclear ${ }^{33}$. What the markets had to expect, though, was that there were no Bank Rate rises scheduled as long as the spare capacity persisted, which could take years. And when these rises eventually came, they would be very fragmented and small. Apparently, this second form of FWG worked, because the statistics show that since 2013, the markets have 
resumed their cuts in most of the interest rates they offer to households and businesses, and so have supported consumption and investment ${ }^{34}$.

The MPC did not decide on its own to have recourse to FWG. The Chancellor, assisted by Chief Economic Adviser Rupert Harrison, was the instigator of the move which was part of a far broader plan designed to put the United Kingdom's economy back on track. The plan was revealed in the 2013 Budget and comprised four pillars. The first pillar was entitled "Monetary activism ${ }^{35}$ " and included two sections, one about "Monetary policy" and the other about "Credit easing". The first section presented the updated remit that Osborne was sending to the $\mathrm{MPC}^{36}$ and that he assimilated to a monetary "reform" in his Budget statement.

In 2013, the move to the use of unconventional policy instruments, and especially FWG, attracted much media attention for various reasons. First, in his Budget statement, Osborne chose to elaborate on FWG. He went so far as to quote the option of intermediate thresholds and the example of the Fed which was using the unemployment rate ${ }^{37}$. He thus gave the media plenty to speculate about. Second, the newly appointed Governor, 47year-old and charismatic Carney, Governor of the Bank of Canada and Chairman of the Financial Stability Board of the G20, was frequently put in the spotlight and always associated to his role in the use of unconventional monetary instruments in Canada. Third, the MPC's announcement of the use of the 7\% unemployment threshold was the most concrete and visible outcome of the strategy.

Yet, FWG should not be regarded as the main feature of Osborne's monetary policy reform. By 2014, in the section of the remit dedicated to "Unconventional policy instruments", the Chancellor reduced his advocacy to the mere statement that the use of FWG was left to the discretion of the MPC. Any reference to the "thresholds", which had been written no less than three times in the updated remit of 2013, was erased. By contrast, what remained was the more general requirement of the creation of a solid governance and accountability system when unconventional interventions may affect credit risk or credit allocation. To illustrate this point, the Chancellor retained the examples of the APF and the FLS. So in the end, what the reform permanently brought in the area of unconventional policy instruments was a clarification of when they could be used and what governance change should accompany their implementation.

The monetary policy reform concerned two other areas. One was the flexibility of the framework and the second was the relationship between monetary stability and financial stability. As a matter of fact, these two areas were closely intertwined in the reform. First, the updated remit went further than the traditional acceptance of inflation target overshoots or undershoots due to exceptional shocks and disturbances. The reform actually acknowledged the responsibility of the MPC in the potential deviations, by saying that the Committee may "wish" to allow deviations. Then, two circumstances for these voluntary deviations were identified. The first was the consideration of "short-term trade-offs" between the need to return inflation to the target and the risk to cause undesirable volatility in output. The remit went on with the specific claim for clear explanations from the MPC about how the trade-offs influenced the Committee's previsions and decisions. The second circumstance, though not exactly expressed in these terms, can be summed up by the consideration of trade-offs between the need to return inflation to the target and the risk to contribute to financial instability. The monetary reform stipulated that the MPC and the Financial Policy Committee should "have regard" to the policy actions of the other. Consequently, a last section added to the remit 
announced overlap in membership of the two Committees, and required each of the institutions to include, inside their various accountability publications, explanations about how they had regard to the other's actions.

In the end, the reform ${ }^{38}$ was not the total overhaul of monetary policy that was pressed by commentators and pressure groups like Positive Money, but that the Treasury's thorough preparatory work had discarded. The preparation had taken the form of a review of no fewer than 62 pages, along which the Treasury had examined the performance of the British monetary policy framework and explored alternatives in the light of evolving monetary policies around the world. The option of an exchange of the CPI for another measure of inflation (like core inflation, nominal wage inflation and asset price inflation) had been analysed and rejected. So had the hypothesis of abandoning IT altogether for the alternatives of price level targeting, nominal GDP growth targeting or nominal GDP level targeting. In the end, the Treasury had concluded that the existing flexible IT framework had served the United Kingdom well and should be maintained ${ }^{39}$. This came as a disappointment for some who had hoped a lot more with Carney's appointment as Governor of the Bank of England.

As a foreigner, Carney was largely unknown by the British lay public, but he rapidly became the object of the press scrutiny. His general remark on the potential necessity, in extraordinary circumstances, to relinquish the IT framework in favour of a targeting of a nominal GDP level ${ }^{40}$ did not go unnoticed. That was what the self-called Market Monetarists, led by Danish economist Lars Christensen, had been recommending for some time ${ }^{41}$. There were proponents of nominal GDP targeting in the United Kingdom too, and they were sometimes quite insistent, like the Financial Times's economic commentator Samuel Brittan ${ }^{42}$. So suddenly there were widespread speculation and arguments about whether Osborne would make the leap. But eventually, the Treasury concurred with the more conservative opinion of outgoing Governor King who strongly defended the IT framework ${ }^{43}$. Therefore, British monetary policy is still subordinated to the priority to keep inflation low and stable in the long term, as defined by the target of $2 \%$ inflation in the medium term.

\section{The 2013 Reform in the Dynamic of Monetary Theories}

The 2013 monetary policy reform should be valued for the fact that it brought clarification in the Government's position regarding two ongoing monetary policy debates, the first of which is the "rule versus discretion" debate. This debate opposes the value of a policy constrained by the strict respect of rules (such as the reduction of money supply aggregates to planned quantitative levels, or the stability of exchange rates at fixed levels in a monetary system), to that of a policy left to the entire discretion of the monetary authorities ${ }^{44}$. According to economists Finn Kydland and Edward Prescott, rules guarantee the time-consistency of a policy, that is to say long-term outcomes that correspond to the policy objective ${ }^{45}$. But discretion permits the authorities to adapt their response to destabilising events in order to smooth the effects they may produce.

In a now widely-quoted article, Ben Bernanke and Frederic Mishkin identified IT as a framework reconciling rule with discretion. The economists argued that, in practice, IT was not a strict rule, but a framework ensuring "constrained discretion": The central 
banks actually dealt with short term issues like output and employment provided that did not affect their meeting of the long-term objective of stable inflation ${ }^{46}$. At the Bank of England, King did not think differently. When still Deputy Governor in 1997, he presented IT as a framework guaranteeing that central banks were not left with "unfettered discretion ${ }^{47}$ ". Like Bernanke and Mishkin, he insisted on the fact that monetary policy had two components: an inflation target and a response to shocks. He explained that faced with a supply shock, the central banks were confronted with a trade-off between the volatility of inflation and the volatility of output, and their role was to properly choose which time horizon was the best to return inflation to target without too much damage on output. Adding to the works of John Taylor ${ }^{48}$, King stated that the optimal targeting horizon depended on the nature and persistence of shocks. For many supply shocks a two year horizon was reasonable. But when shocks were larger, there might be a need to extend this horizon. The goal of the Governor's open letter, when the inflation target was missed, was to inform on this extension.

In light of King's discourse, it is obvious that the remit updated in 2013 simply officialised a situation that already existed regarding the dual component of monetary policy and the extent of the discretionary powers of the Bank of England. So in practice, there was nothing new. But the message had obviously not been understood previously. Indeed, the remits published before 2013 had been short on developments and explanations about discretion. That deficiency was of no consequence as long as there were no major crises. But since 2008, there was a growing need to complement the message, to explain why the MPC seemed gradually more focused on output than on inflation. Indeed, inflation deviations from target went on occurring without causing much official stir. At the same time, the emergence of operations concerted with the Government, like the FLS, gave the impression that the Bank of England was more and more required to support the Government's objective for growth, rather than to maintain price stability. The misunderstanding of the true mechanism of monetary policy action added to the confusion of the markets and needed to be cleared up. As it turned out, the Government's clarification about the trade-off between inflation and output volatility was often interpreted as a step towards more discretion.

31 In reality, the main move towards more discretion was rather the positioning of the coalition Government in a second debate called the "lean versus clean" debate. In this debate, the question is to decide whether monetary policy has a role to play in the prevention of asset price bubbles (leaning against the wind) or should only focus on restoring the macroeconomic situation back to normal if bubbles burst (cleaning the mess) ${ }^{49}$. This debate had long existed. In the United Kingdom, the "clean" side had arguably won the argument, with the definition of monetary policy written in the Bank of England Act 1998, even if some research revealed the MPC had actually responded to financial market volatility ${ }^{50}$. But the debate had naturally reopened with the financial crisis and its economic aftermath. At the Bank of England, outgoing Governor King was of the unshakable opinion that central banks should not use the Bank Rate for financial stability objectives ${ }^{51}$. But incoming Governor Carney was fuelling the debate. He believed that even if the prevention of financial bubbles was first a matter of micro- and macroprudential regulation and supervision, there might be a point at which monetary policy would be the last line of defence ${ }^{52}$. Eventually, the coalition Government found a consensus. Osborne did not modify the objective of monetary policy by giving the MPC the role of ensuring financial stability. Rather, another committee, the FPC, was 
(re)created to deal with the latter objective. Nevertheless, the monetary policy reform of 2013 actually managed to link the two intertwined objectives of monetary and financial stability ${ }^{53}$.

The reform of the British monetary policy framework was embedded in the context of the progress of monetary theories in the light of a situation that was encountered worldwide for the first time. IT frameworks had never been confronted with such a large scale financial crisis. As for the hypothesis of the Bank Rates stuck at the zero lower bound, it had always been a "theoretical curiosity ${ }^{54 "}$. In the end, the IT frameworks stood the test and their flexibility provided adequate responses, but the crisis had raised many interrogations in the fields of economic analysis in general ${ }^{55}$ and monetary policy in particular. When economists did not ask for a scrap of IT altogether, they proposed the kinds of improvement that the British coalition Government adopted ${ }^{56}$. Indeed, a worldwide recurring recommendation was that of spreading the use of FWG, with a clear statement about future policy intentions linked to specific economic conditions, whether these conditions were still anomalous or back to normal. Another repeated instruction was that of keeping monetary policy as a last line of defence, but securing coordination between monetary and macro-prudential policies ${ }^{57}$. A thorough comparison with the evolution of the IT frameworks in the major economies would allow for a better measure of global influences.

Yet, the coalition Government should not be detracted from the paternity of its reform. The monetary policy reform may even appear as a truly Conservative move, and not only because it respected the principles set by John Major's Government as of 1992. Indeed, it was an echo of the vision the Conservatives had of monetary policy when arriving in power in 1979, which was that of "monetary activism". The first Thatcher Government had heavily relied on the Medium Term Financial Strategy to create the optimal stability conditions for economic growth, while trying on the other hand to cure the budget from its deficit and from debt evils ${ }^{58}$. In 2013, Cameron was strongly backing his Chancellor's strategy of fiscal conservatism combined with monetary activism ${ }^{59}$. In both cases, the Governments had the same discourse: They said monetary stability was a pre-condition, but was not sufficient to ensure economic growth and employment. And in both cases, they seemed to put too much faith in the potency of monetary policy to restore growth. Furthermore, a rather Conservative approach may be recognized in the hands-on behaviour of Osborne regarding monetary policy. Even though the Government did not attempt to repeal the monetary policy sections of the Bank of England Act 1998 that ensured the operational independence of the MPC, the Chancellor went as far as he could to intervene in the MPC's work within the legal constraint.

\section{Conclusion}

The financial crisis of 2008 and the subsequent recession forced emergency measures. Next, they called into question the validity of the existing monetary framework dedicated to price stability. The framework was thus revised as of 2013. First, the use of unconventional instruments by the Bank of England was officially authorised and the terms of the regulation of such a use were reaffirmed. Second, the scope of the discretion allocated to the Bank in the consideration of the trade-off between inflation volatility and output volatility was clarified. Third, supplementary discretion was granted in the context of more coordination between monetary and financial policies. 
Yet, in light of the impressive scale of the economic shock, these alterations are relatively limited. The essentials of IT have officially survived. It is true that the Bank of England is claiming a focus on price stability whereas it seems to be targeting growth and employment. But supporting the Government's objectives for growth and employment is consistent with the Bank of England Act 1998, as long as this does not conflict with price stability. And in fact, since 2013, targeting growth and employment has served the objective of price stability, because the monetary easing that the former requires has also been needed to break the steady decelerating trend of inflation ${ }^{60}$.

The financial crisis of 2008 and its aftermath have therefore not completely disrupted the British economic and political consensus in favour of the IT strategy. This raises again the question of whether IT is not the end of monetary policy history ${ }^{61}$ - the final outcome of centuries of thinking and tests, that will continue to be modified and improved, but that will not disappear. The future will tell, but one may already wonder about what would happen if a situation of deep stagflation occurred again one day and opposed the objectives of price stability on the one hand and growth and employment on the other. So far, the resilience of the British IT framework does not seem to have been fully tested.

Nathalie Champroux, $\mathrm{PhD}$, is associate professor at University Paris Est Créteil and researcher at CERVEPAS/CREW EA 4399, Sorbonne Nouvelle - Paris 3. One of her two research subjects is British monetary policy since 1976.

\section{Appendix}

Figure 1: GDP growth, UK, 2003-2015

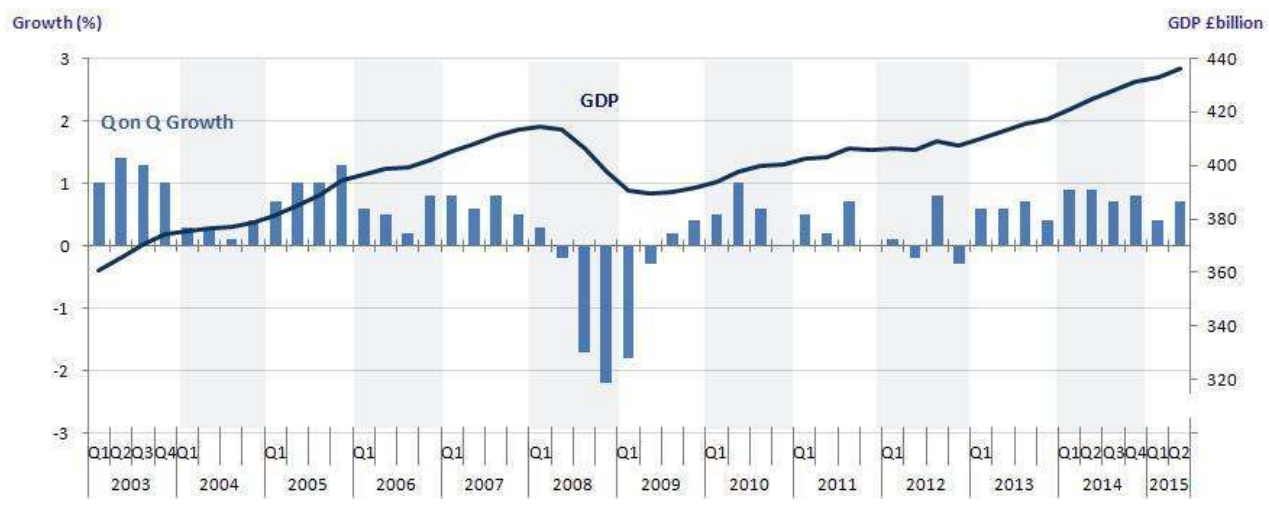

Source: Office for National Statistics 
Figure 2: Short-term interest rates, UK, 2003-2016

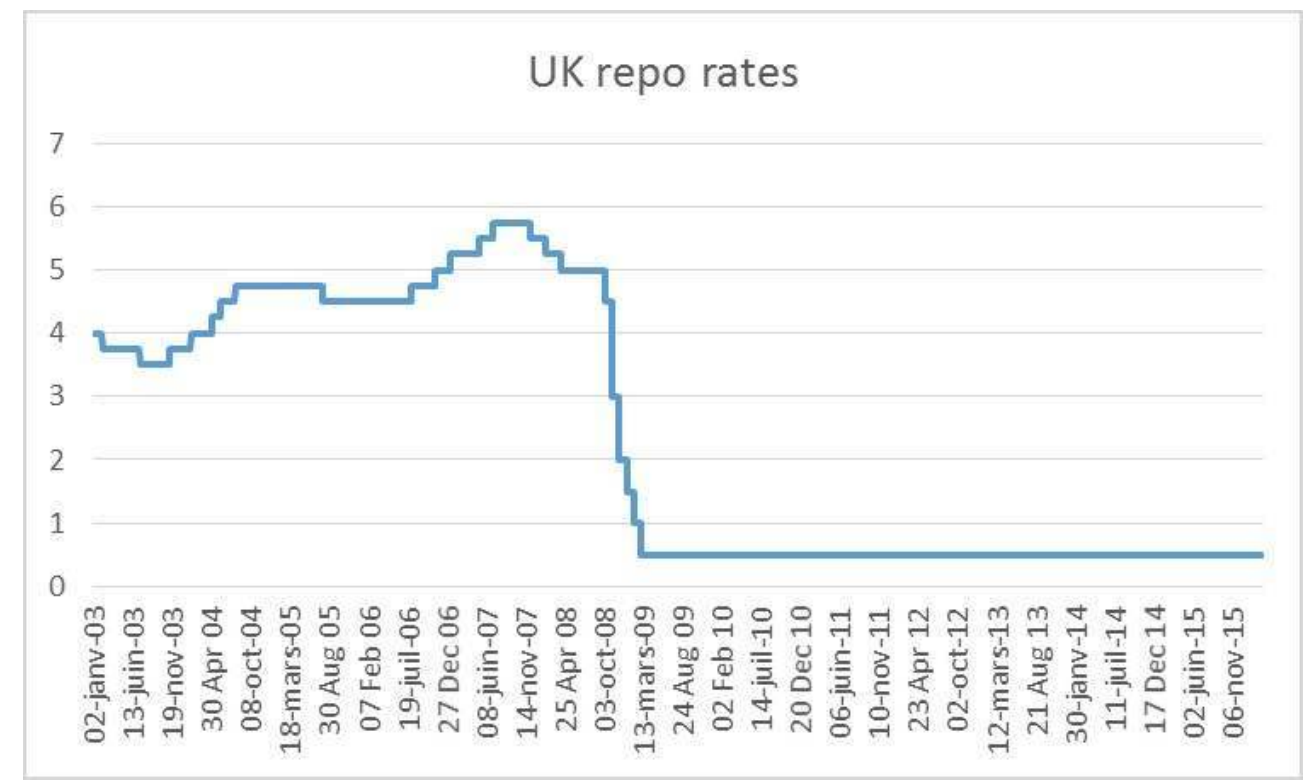

Source: Bank of England

Figure 3: Inflation, UK, 2003-2016

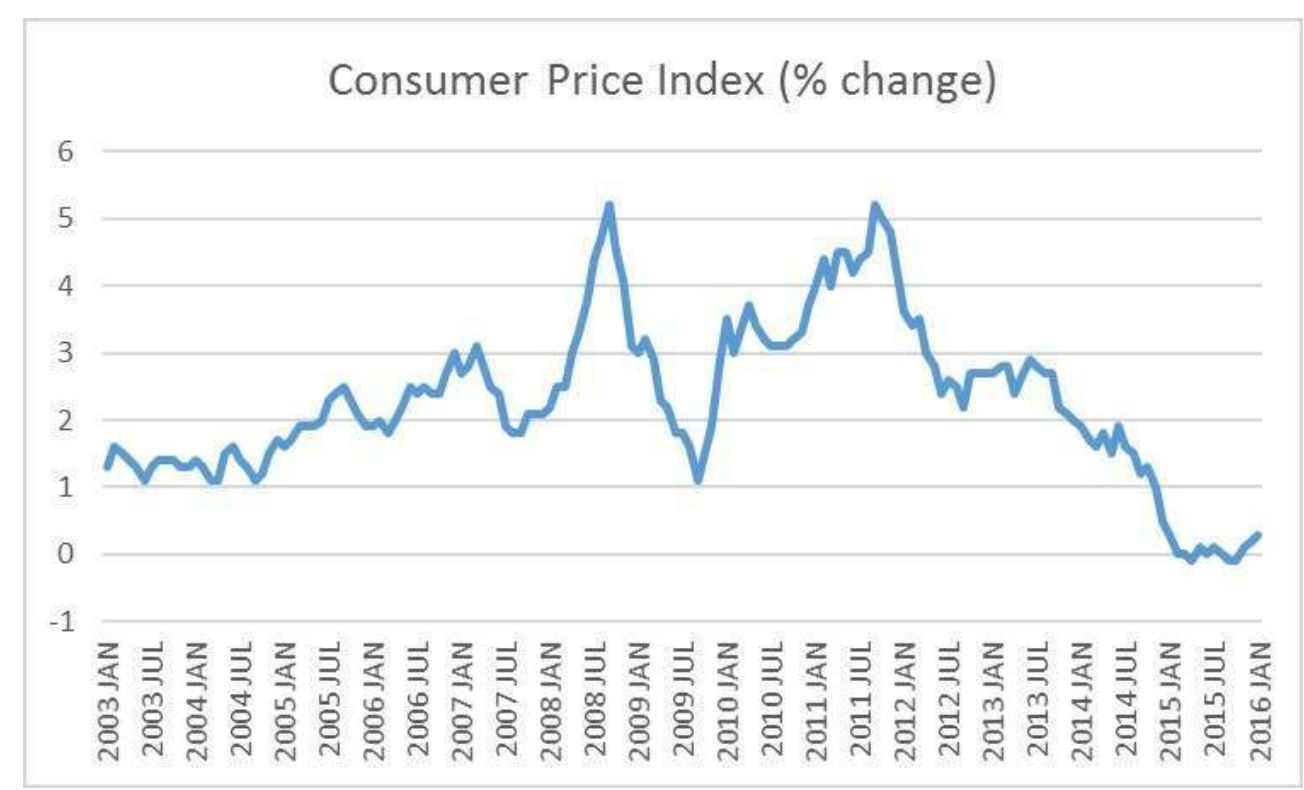

Source: Office for National Statistics 


\section{BIBLIOGRAPHY}

ARESTIS Philip \& MIHAILOv Alexander, "Flexible rules cum constrained discretion: a new consensus in monetary policy", Working paper, No 053 (Henley Business School - University of Reading, October 2007).

BANK OF ENGLAND, "Report: The Monetary Policy Committee of the Bank of England: ten years on", Quarterly Bulletin, Vol. 47, No. 1 (2007 Q1).

BANK OF ENGLAND, The Bank of England Act 1998, the Charters of the Bank and related documents (July 2015).

BERG Claes, "The Global Financial Crisis and the Great Recession: Causes, Effects, Measures and Consequences for Economic Analysis and Policy", Paper presented at a Workshop on Monetary Policy, Macroprudential Policy and Fiscal policy at the Centre for Central Banking Studies of Bank of England 17 May-19 May 2011 (Bank of England, 23 May 2011).

BERNANKE Ben \& MISHKIN Frederic, "Inflation targeting: A new framework for monetary policy”, Working Paper, No 5893 (National Bureau of Economic Research, January 1997).

CARNEY Mark, "Guidance", Remarks at the CFA Society Toronto (Toronto, 11 December 2012).

CARNEY Mark, "Monetary Policy After the Fall", Eric J. Hanson Memorial Lecture at the University of Alberta (Bank of Canada, 1 May 2013).

CRESPO CUARESMA Jesús \& GNAN Ernest, "Four Monetary Policy Strategies in Comparison: How to Deal with Financial Instability", Monetary Policy and the Economy (Oesterreichische Nationalbank, Q3 2008), pp. 65-102.

DODGE David, "Our approach to monetary policy - inflation targeting", Remarks to the Regina Chamber of Commerce, (Regina, 12 December 2005).

FILARDO George \& HOFMANN Boris, "Forward guidance at the zero lower bound", BIS Quarterly Review (Bank for International Settlements, March 2014), pp. 37-53.

GOODHART Charles et al., “Monetary targetry: Might Carney make a difference?”, VOX (CEPR's Policy Portal, 22 January 2013).

HM TREASURY, Review of HM Treasury's management response to the financial crisis, PU1286 (House of Commons, March 2012).

HM TREASURY, Budget 2013, HC 1033 (House of Commons, 20 March 2013).

HM TREASURY, Review of the monetary policy framework, CM 8588 (House of Commons, March 2013).

KING Mervyn, "Changes in UK monetary policy: Rules and discretion in practice", Journal of Monetary Economics, Vol. 39 (1997), pp. 81-97.

KING Mervyn, "The Inflation Target five years on", Lecture at the London School of Economics (Bank of England, 29 October 1997).

KING Mervyn, "Finance: A Return from Risk", Speech to the Worshipful Company of the International Bankers at Mansion House (Bank of England, 17 March 2009). 
KING Mervyn, "Twenty years of inflation targeting”, The Stamp Memorial Lecture, London School of Economics (Bank of England, 9 October 2012).

KING Mervyn, "Speech at the CBI Northern Ireland Mid-Winter Dinner, Belfast" (Bank of England, 22 January 2013).

KYDLAND Finn \& PRESCOTT Edward, "Rules Rather than Discretion: The Inconsistency of Optimal Plans." Journal of Political Economy, Vol. 85 (1977), pp. 473-91.

LAMONT Norman, Letter to John Watts (8 October 1992).

MISHKIN Frederic, “Monetary policy strategy: Lessons from the crisis”, Working Paper, No 16755 (National Bureau of Economic Research, February 2011).

MONETARy POlicy COMmitTeE, "Minutes of Monetary Policy Committee Meeting” (Bank of England).

OSBORNE George, “Budget 2013: Chancellor’s Statement” (House of Commons, 20 March 2013).

JoycE Michael et al., “The United Kingdom's quantitative easing policy: design, operation and impact", Quarterly Bulletin (Bank of England, 2001 Q3), pp. 200-212.

TAYLOR John B, "Discretion versus policy rules in practice", Carnegie-Rochester Conference Series on Public Policy, Vol. 39 (1993), pp. 195-214.

WOODFORD Michael, "Monetary Policy Targets After the Crisis", Paper presented at the Rethinking Macro Policy II: First Steps and Early Lessons Conference Hosted by the International Monetary Fund (Washington, April 16-17 2013).

\section{NOTES}

1. HM TREASURY, Review of HM Treasury's management response to the financial crisis, PU1286 (House of Commons, March 2012), p. 19.

2. The law did not only concern monetary policy, but also the supervision and regulation of the financial services industry.

3. "Bank of England Act 1998", in BANK OF ENGLAND, The Bank of England Act 1998, the Charters of the Bank and related documents (July 2015), Chapter 11, Part II: Monetary policy, pp. 50-55.

4. HM TREASURY, Budget 98: New Ambitions for Britain, The Financial Statement and Budget Report (House of Commons, March 1998), pp. 17-18.

5. L AMONT Norman, Letter to John Watts (8 October 1992), <http:// webarchive.nationalarchives.gov.uk/20130304161249/http://www.hm-treasury.gov.uk/d/ foi_dis_7_john_watts_081092.pdf> [25 September 2015].

6. HM TREASURY, The strength to take the long-term decisions for Britain: Seizing the opportunities of the global recovery, Pre-Budget Report, CM 6042 (House of Commons, December 2003), pp. 15-17.

7. Four-quarter inflation rates, BANK OF ENGLAND, "Report: The Monetary Policy Committee of the Bank of England: ten years on", Quarterly Bulletin, Vol. 47, No. 1 (2007 Q1), p. 26.

8. CPI rates in TRIAMI MEDIA BV, "Table: average inflation Great Britain (CPI) - by year", inflation.eu, Utrecht, ‘http://www.inflation.eu/inflation-rates/great-britain/historic-inflation/ cpi-inflation-great-britain.aspx ${ }^{3}$ [25 September 2015].

9. "Nice" stands for "non-inflationary consistently expansionary", an expression used by the Governor of the Bank of England, Mervyn King. See Mervyn King, Speech, 14 October 2003, East Midlands Development Agency/Bank of England Dinner, Leicester.

10. BANK OF ENGLAND, "Report: The Monetary Policy Committee of the Bank of England: ten years on", op. cit., pp. 24-38. 
11. See the electronic site of the Bank of England, ¿http://www.bankofengland.co.uk/ monetarypolicy/Pages/default.aspx' [25 September 2015].

12. HM TRESAURY, Review of HM Treasury's management response to the financial crisis, PU1286 (House of Commons, March 2012), Annex B: Policy Interventions, p. 57.

13. For a comprehensive view of Bank Rate cuts, see Figure 2, Appendix, infra.

14. See monetary policy committee, "Minutes of Monetary Policy Committee Meeting", Bank of England (19 December 2007); (20 February 2008); (23 April 2008).

15. For a comprehensive view of inflation fluctuation, see Figure 3, Appendix, infra.

16. See Champroux Nathalie, "British and American monetary policies convergence: structural coincidence or transatlantic mutual influence?", in GRoUTEL Anne, cossu-BEAUMONT Laurence, P AUWels Marie-Christine \& PEYRonel Valérie (eds.), Revisiting the UK and Ireland's Transatlantic Economic Relationship with the United States in the 21st Century, Beyond Sentimental Rhetoric (Palgrave MacMillan, 2016).

17. The MPC was not fully right this time. The actual inflation rate increasingly overshot the target, from 2010 until April 2012. The Committee blamed temporary factors like the increase in the standard rate of Value-Added Tax, the fall in sterling and the steep increases in import and energy prices.

18. DARLING Alistair, "CPI Inflation", Reply from the Chancellor to the Governor (17 June 2008);

(15 September 2008); (16 December 2008); (24 March 2009).

19. MONETARY POlicy COMmittee, "Minutes of Monetary Policy Committee Meeting 4 and 5 February 2009" (Bank of England, 18 February 2009).

20. DARLING Alistair, "Asset Purchase Facility", Letter from the Chancellor to the Governor (3 March 2009).

21. D ARLING Alistair, "Extending Asset Purchase Facility", Letter from the Chancellor to the Governor (6 August 2009); (5 November 2009).

22. See JoycE Michael et al., "The United Kingdom's quantitative easing policy: design, operation and impact", Quarterly Bulletin (Bank of England, 2001 Q3), pp. 200-212.

23. For a comprehensive view of GDP growth, see Figure 1, Appendix, infra.

24. See OsBoRNE George, "CPI inflation", Reply from the Chancellor to the Governor (18 May 2010) and HM TRESAURY, Budget 2010, HC 61 (House of Commons, 22 June 2010), p. 14.

25. Compare D ARLING Alistair, "Remit for the Monetary Policy Committee - March 2010" (24 March 2010) to OSBORnE George, "Remit for the Monetary Policy Committee - March 2011" (23 March 2011).

26. Trends from OfFICE FOR NATIONAL STATISTICS, Statistical Bulletin: Gross Domestic Product Preliminary Estimate, Quarter 2 (April to June) 2015, (TSO, 28 July 2015), p. 5.

27. OsBoRnE George, “Budget 2013: Chancellor's Statement” (House of Commons, 20 March 2013).

28. See, for example, OSBORNE George, "CPI inflation", Reply from the Chancellor to the Governor (18 May 2010); (14 February 2012).

29. For the various arguments put forward, see MONETARY POLICY COMMITTEE, "Minutes of Monetary Policy Committee Meeting 5 and 6 June 2013" (Bank of England, 19 June 2013).

30. For details about the various forms of FWG implemented by these central banks, see FILARDO George \& HOFMANN Boris, "Forward guidance at the zero lower bound", BIS Quarterly Review (Bank for International Settlements, March 2014), pp. 37-53.

31. Monetary Policy committee, "Minutes of Monetary Policy Committee Meeting 31 July and 1 August 2013" (Bank of England, 14 August 2013).

32. BANK OF ENGLAND, Inflation Report (February 2014), p. 7.

33. monetary policy Committee, "Minutes of Monetary Policy Committee Meeting 7 and 8 May 2014" (Bank of England, 21 May 2014), pp. 10-11. 
34. As far as households are concerned, the average interest rates on unsecured loans $(£ 10,000)$ decreased, from nearly 7\% down to slightly more than 4\%, between 2013 and the beginning of 2016. The rates on two-year fixed-rate mortgages (75\% loan to value) also decreased, from about $3 \%$ down to less than $2 \%$, over the same period (See BANK OF ENGLAND, Inflation Report (November 2015), chart 2.4, p. 14). For 2013-2014, households' consumption growth remained resilient, by $0.6 \%$. So did private sector business investment growth, by $1.1 \%$ (Ibid., Table 2.B p. 12), while interest rates on lending to SMEs tended to decrease from 2013 onward (See BANK OF ENGLAND, Credit Condition Review (Q3 2015), chart 3.3, p. 14).

35. The other three pillars were "Deficit reduction", "Reform of the financial system" and "Structural reforms". See HM TRESAURY, Budget 2013, HC 1033 (House of Commons, 20 March 2013), p. 16.

36. OsBoRnE George, "Remit for the Monetary Policy Committee - March 2013" (20 March 2013).

37. OSBORNE George, "Budget 2013: Chancellor's statement", op. cit.

38. There were two other minor changes. A new timing for the open letter process was set. And the list of the four pillars of the Government's economic strategy was copied into the section describing the Government's objectives.

39. See HM TRESAURY, Review of the monetary policy framework, CM 8588 (House of Commons, March 2013).

40. CARNEY Mark, "Guidance", Remarks at the CFA Society Toronto (Toronto, 11 December 2012).

41. See, for example, CHRISTEnSEn Lars, "Market Monetarism - The Second Monetarist Counterrevolution”, (13 September 2011), ‘https://thefaintofheart.files.wordpress.com/2011/09/ market-monetarism-13092011.pdf ${ }^{>}$[25 September 2015].

42. Note that Brittan defended a target of nominal GDP growth. See explanations in GoodHART Charles et al., "Monetary targetry: Might Carney make a difference?", VOX (CEPR's Policy Portal, 22 January 2013), ‘http://www.voxeu.org/article/monetary-targetry-might-carney-makedifference ${ }^{>}$[25 September 2015].

43. See KING Mervyn, "Speech at the CBI Northern Ireland Mid-Winter Dinner, Belfast" (Bank of England, 22 January 2013).

44. For an overview of the debate in neoclassical and then New Keynesian literature, see ARESTIS Philip \& MIHAILOV Alexander, "Flexible rules cum constrained discretion: a new consensus in monetary policy", Working paper, No 053 (Henley Business School - University of Reading, October 2007).

45. K ydland Finn \& PREscotT Edward, "Rules Rather than Discretion: The Inconsistency of Optimal Plans.” Journal of Political Economy, Vol. 85 (1977), pp. 473-91.

46. B ERNANKE Ben \& MISHKIN Frederic, "Inflation targeting: A new framework for monetary policy”, Working Paper, No 5893 (National Bureau of Economic Research, January 1997).

47. KING Mervyn, "The Inflation Target five years on", Lecture at the London School of Economics (Bank of England, 29 October 1997). Also read about the various econometric models of the tradeoff between rules and discretion in KING Mervyn, "Changes in UK monetary policy: Rules and discretion in practice”, Journal of Monetary Economics, Vol. 39 (1997), pp. 81-97.

48. TAYLOR John B, "Discretion versus policy rules in practice", Carnegie-Rochester Conference Series on Public Policy, Vol. 39 (1993), pp. 195-214.

49. On this debate, and the question of which kind of bubble can be prevented according to the nature of assets, see MisHKIN Frederic, "Monetary policy strategy: Lessons from the crisis", Working Paper, No 16755 (National Bureau of Economic Research, February 2011).

50. See CRESPO CUARESMA Jesús \& GNAN Ernest, "Four Monetary Policy Strategies in Comparison: How to Deal with Financial Instability", Monetary Policy and the Economy (Oesterreichische Nationalbank, Q3 2008), pp. 65-102. 
51. See KING Mervyn, "Finance: A Return from Risk", Speech to the Worshipful Company of the International Bankers at Mansion House (Bank of England, 17 March 2009); "Twenty years of inflation targeting", The Stamp Memorial Lecture, London School of Economics (Bank of England, 9 October 2012).

52. See CARNEY Mark, "Monetary Policy After the Fall”, Eric J. Hanson Memorial Lecture at the University of Alberta (Bank of Canada, 1 May 2013).

53. On the financial stability aspect, see in the present book the article by ESPOSITO Marie-Claude.

54. CARNEY Mark, "Monetary Policy After the Fall", op. cit.

55. See BERG Claes, "The Global Financial Crisis and the Great Recession: Causes, Effects, Measures and Consequences for Economic Analysis and Policy", Paper presented at a Workshop on Monetary Policy, Macroprudential Policy and Fiscal policy at the Centre for Central Banking Studies of Bank of England 17 May-19 May 2011 (Bank of England, 23 May 2011).

56. For other kinds of proposals, see The Economist, "Monetary policy after the crash", 21 September 2013, ¿http://www.economist.com/news/schools-brief/21586527-third-our-seriesarticles-financial-crisis-looks-unconventional' [25 September 2015].

57. See MISHKIN Frederic, "Monetary policy strategy: Lessons from the crisis", op. cit; and wOoDFoRD Michael, "Monetary Policy Targets After the Crisis", Paper presented at the Rethinking Macro Policy II: First Steps and Early Lessons Conference Hosted by the International Monetary Fund (Washington, April 16-17 2013).

58. See Champroux Nathalie \& Sowels Nicholas, "The Monetary and Fiscal Policies of Early Thatcherism and the Legacy of the Medium Term Financial Strategy", in ESPIET-KILTY Raphaelle (ed.), L'héritage du thatchérisme, Review Observatoire de la société britannique, La Garde, No 17 (November 2015), pp. 135-159.

59. See тном⿰оп Ainsley, “Cameron Backs 'Activist' Monetary Policy”, The Wall Street Journal (11 October 2010).

60. In fact, as regards inflation only, more monetary easing should have been implemented, in 2013 and 2014 at least. See BANK OF ENGLAND, Inflation Report (February 2016), chart 4.1, p. 26.

61. On the debate of whether IT is the outcome of monetary theories and practices, or "the end of monetary policy history", see CARNEY Mark, "Monetary Policy After the Fall”, op. cit., as well as the initial view of DODGE David, "Our approach to monetary policy - inflation targeting”, Remarks to the Regina Chamber of Commerce, (Regina, 12 December 2005).

\section{ABSTRACTS}

This article demonstrates the extent and limits of the consequences that the 2008 financial crisis and the subsequent economic recession had on Britain's monetary policy framework. It shows that, beyond the activation of unconventional practices, the crisis caused a reform that was not a complete overhaul of the framework. The bases of the framework dedicated to inflation targeting have been maintained. The value of the reform nonetheless resides in the clarification of the principles of the flexibility of the system and in a move towards a better coordination between monetary and financial policies. The reform is thus embedded in the global progress of monetary theories. 
L'article démontre l'étendue et les limites des conséquences que la crise financière de 2008 et la récession économique qui a suivi ont eues sur le cadre de politique monétaire britannique. Il montre que, au-delà de l'activation de pratiques non-conventionnelles, la crise a entraîné une réforme qui n'a pas été une refonte totale du système. Les bases du cadre consacré au ciblage de l'inflation ont été maintenues. La valeur de la réforme réside néanmoins dans le fait qu'elle clarifie les principes de la flexibilité du système et avance dans la direction d'une meilleure coordination entre les politiques monétaire et financière. La réforme s'inscrit ainsi dans l'évolution générale des théories monétaires.

INDEX

Keywords: monetary policy framework, inflation targeting, interest rates

Mots-clés: cadre de la politique monétaire, ciblage de l'inflation, taux d'intérêt

\section{AUTHOR}

NATHALIE CHAMPROUX

Université Paris Est Créteil 